Uloga Streptococcus mutans grupa i imunoglobulina pljuvačke u etiologiji

karijesa ranog detinjstva

\title{
The Role of Streptococcus mutans group and salivary immunoglobulins in etiology of early childhood caries
}

\author{
Andrijana Cvetković ${ }^{1}$, Mirjana Ivanović ${ }^{2}$ \\ ${ }^{1}$ Medicinski fakultet Univerziteta u Prištini, Klinika za dečju i preventivnu stomatologiju, \\ Kosovska Mitrovica. \\ ${ }^{2}$ Stomatološki fakultet Univerziteta u Beogradu, Klinika za dečju i preventivnu stomatologiju.
}

INFORMATIVNI RAD (IR) INFORMATIVE ARTICLE

\begin{abstract}
KRATAK SADRŽAJ
Pojava karijesa ranog detinjstva se dovodi $u$ vezu sa greškama u ishrani odojčeta, međutim mehanizam nastajanja oboljenja je mnogo složeniji. Da bi razumeli etiologiju karijesa potrebno je razumeti ekologiju oralne sredine i ustanoviti koji su činioci odgovorni za prelaz nepatogenih (nekariogenih) mikroorganizama usne duplje u patogene (kariogene). Imunoglobulini pljuvačke (SIgA) obrazuju mehanizam specifične imune odbrane u pljuvački i imaju važnu ulogu u oralnoj homeostazi. Osnovna uloga salivarnih imunoglobulina je u kontroli bakterijske oralne flore $i$ uspostavljanju ravnotežnog odnosa između bakterija usne duplje i organizma kao celine. U radu je uz opisane kliničke karakteristike karijesa ranog detinjstva pregledno prikazana etiologija ovog obolenja uključujući do sada prihvaćene stavove o mogućoj ulozi imunoglobulina pljuvačke u pojavi karijesa ranog detinjstva, medu mnogobrojnim faktorima u kontroli oralnaih mikroorganizama.
\end{abstract}

Ključne reči: Karijes ranog detinjstva, , Klinički opis, Etiologija, Streptokokus mutans grupa, Imunoglobulini pljuvačke.

\section{SUMMARY}

Dental caries is a bacterial infective disease modified by carbohydrates from food. Eearly childhood caries is a special type of primary teeth caries in infants and toddlers. Appearance of early childhood caries (ECC) is related to mistakes in nutrition of infants, but the mechanism of beginning and progression of this disease is very complex. To understand etiology of caries, it is necessary to understand ecology of oral environment and to determine which factors are responsible for conversion of non-pathogenic microorganisms of the oral cavity into pathogenic. Among host factors, salivary immunoglobulin (sIgA) constitutes the main specific immune defense mechanism in saliva and may play an important role in the oral homeostasis. Basic role of salivary immunoglobulins is in control of bacterial oral flora and constitution of balance relationship between oral bacteria and organism as whole.

Key words: Early Childhood Caries, Clinical description, Etiology, Streptococcus mutans group, Salivary immunoglobulins.
U uslovima koji vladaju u oralnoj sredini nakon nicanja mlečnih zuba, a koji su najčešće predisponirajući za pojavu karijesa (nepravilna ishrana, loša oralna higijena i dr.) dolazi do rane infekcije visokim stepenom kolonizacije Streptococcus mutans grupa. Ovo može dovesti do pojave karijesa ranog detinjstva i povećanja karijes rizika kod te dece u starijem uzrastu ${ }^{1,2,3}$.
Conditions in the oral environment after the eruption of deciduous teeth are in favour of caries development (inadequate nutrition, bad oral hygiene etc.). Early infection of Strptococcus mutans group with high degree of colonization lead to early childhood caries and high caries risk in these children at elder age. 1,2,3 
Pojava karijesa ranog detinjstva (KRD) se dovodi u vezu sa greškama u ishrani odojčeta, ${ }^{4,5}$ međutim mehanizam nastajanja i progresije ovog oboljenja je mnogo složeniji. Da bi razumeli etiologiju karijesa potrebno je razumeti ekologiju oralne sredine i ustanoviti koji su činioci odgovorni za prelaz nepatogenih (nekariogenih) mikroorganizama usne duplje u patogene (kariogene) ${ }^{6}$. Značajnu ulogu u ovim procesima imaju imunoglobulini pljuvačke koji zahvaljujući mehanizmima specifične imune odbrane imaju važnu ulogu u oralnoj homeostazi. ${ }^{6,7,8}$

Osnovna uloga imunoglobulina pljuvačke je u kontroli bakterijske oralne flore i uspostavljanju ravnotežnog odnosa između bakterija usne duplje i organizma kao celine.

Imunoglobulini tz. sekretornog imunoglobulinskog sistema sintetišu se kao posledica direktne antigene stimulacije organizma iz oralne sredine ${ }^{8,9,10}$. Odrasle osobe su zaštićene SIgA, dok dečja pljuvačka sadrži polovinu koncentracije SIgA u odnosu na odrasle i njegov lokalni nivo je nizak do kraja prve godine života pa i kasnije $\mathrm{e}^{11,12}$. Na osnovu nalaza koncentracija imunoglobulina pljuvačke, smatra se da su sekretorni IgA kvantitativno najznačajniji 8,9,10.

Može se reći da postoji neka vrsta ravnoteže između oralne sredine i mikroorganizama i da svako njeno narušavanje dovodi do manifestacije određenog oboljenja u ovom slučaju karijesa ranog detinjstva. ${ }^{2}$

\section{Kliničke manifestacije karijesa ranog detinjstva}

Karijes ranog detinjstva (KRD) (Drury i sar.,1999) ${ }^{13}$ je u svetu priznat od velikog broja autora, kao najčešći oblik karijesa mlečnih zuba, koji se javlja kod odojčeta i dece predškolskog uzrasta. Poznat je takođe kao cirkularni karijes, karijes loše sredine, karijes bočice sa cuclom, melanodoncija $\mathrm{i}$ td. ${ }^{5,13,14,15}$. Karijes ranog detinjstva se razlikuje od uobičajenih formi karijesa mlečnih i stalnih zuba po svojoj pojavi, vremenu kada se javlja, lokalizaciji, toku i ishodu ${ }^{16,17}$.

Proces karijesa ranog detinjstva uvek počinje na maksilarnim sekutićima, brzo se širi na ostale zube u gornjoj vilici, a tek kasnije i na zube u donjoj vilici ${ }^{5}$. Karijes se obično javlja, na maksilarnim sekutićima, zatim maksilarnim i mandibularnim molarima, ređe na očnjacima, a najređe na mandibularnim sekutićima (Tabela 1$)^{5}$. Tok razvoja karijesa je karakterističan za obolenje jer zavisi od redosleda nicanja mlečnih zuba, vremena trajanja kauzalnih faktora, pokreta oralne musculature ${ }^{18}$. Ovaj oblik karijesa počinje u najranijem uzrastu, često neposredno po nicanju mlečnih zuba, stvaranjem karakterističnih zelenkastomrkih naslaga na labijalnim površinama gleđi vratnog dela krunice maksilarnih sekutića ${ }^{17}$. Zelenkasto mrke naslage nastaju zbog delovanja melanogenih bakterija i prvi su znak da je došlo do poremećaja u flori usne duplje.
Development of early childhood caries (ECE) is connected with mistakes in baby nutrition, ${ }^{4,5}$ but the mechanism of occurrence and development of this disease is much more complex. In order to understand the etiology of caries, it is essential to understand the ecology of oral environment and determine which factors are responsible for conversion of non-pathogen (non-carious) into pathogen (carious) oral microorganisms. ${ }^{6}$ Salivary immunoglobulins play an important role in these processes and, thanks to specific immune defense mechanisms, have a very important role in oral homeostasis. ${ }^{6,7,8}$

The main role of salivary immunoglobulins is the control of bacterial oral flora and establishing the balance between oral bacteria and the host organism.

Immunoglobulins form the secretory immunoglobulin system are synthesized after a direct antigen stimulation from the oral cavity. ${ }^{8,9,10}$ The adults are protected by SIgA, but children's saliva contains only half the concentration of SIgA compared to the adults and their local level is low until the end of first year, and even later. ${ }^{11,12}$ Based on salivary immunoglobulins concentrations, it is believed that secretory $\operatorname{IgA}$ are most important quantitatively. ${ }^{8,9,10}$

It can be stated that there is a sort of the balance between oral environment and microorganisms and that any misbalance in this respect leads to a certain disease, in this case early childhood caries. ${ }^{2}$

\section{Clinical manifestations of early childhood caries}

Early childhood caries (ECC) (Drury et al. 1999.) ${ }^{13}$ is accepted by many authors in the world as the most frequent kind of deciduous teeth caries that occurs in infants and children of pre-school age. It is also known as rampant caries, bad environment caries, nursing caries, melanodontsia etc. ${ }^{5,13-15}$ Early childhood caries differs from the usual forms of caries in deciduous and permanent teeth by its appearance, time of development, localization, course and outcome. ${ }^{16,17}$

Early childhood caries process always starts on maxillary incisors, quickly spreads to other teeth in the upper jaw and then later on mandibular teeth. ${ }^{5}$ Caries is predominantly localized in maxillary incisors, then maxillary and mandibular molars, less frequently in canines and least frequently in mandibular incisors (table 1). ${ }^{5}$ Its development course is characteristic for this disease because it depends on the eruption of deciduous teeth, longevity of causal factors, movements of oral muscles. ${ }^{18}$ This form of caries starts in the earliest age, very often immediately after tooth eruption, with the forming of characteristic green-brownish spots on labial surfaces of cervical enamel in maxillary incisors. ${ }^{17}$ These spots develop because of melanogenic bacteria and they are the first sign of oral flora misbalance. 
Tabela 1. Tipične karakteristike KRD

Tabe 1. Typical characteristics of Early Childhood Caries

Grauwe A. DE., Martens J.K.M. APS. L.C.3

\begin{tabular}{ll}
\hline \multicolumn{2}{l}{ Early Childhood Caries } \\
\hline \hline I. & Brz razvoj. Progresija karijesa iz gleđi u dentin nastaje za 6 meseci ili ranije. \\
II. & Maksilarni sekutići su zahvaćeni prvi. Ovi zubi obicno ničui oko 8 meseca starost. \\
III. & $\begin{array}{l}\text { Sledći zubi koji su zahvaćen su prvi maksilarni i mandibularni mlečni molari, koji počinju da niču oko } 12 \\
\text { meseca starosti. }\end{array}$ \\
IV & $\begin{array}{l}\text { Na kraju, kada bolest postane mnogo teža, sa oštećenjima zuba koja se ne mogu sanirati, zahvaata i } \\
\text { mandibularne sekutiće. }\end{array}$ \\
\hline
\end{tabular}

Gled ispod i oko naslaga ubrzo postaje kredasto bele boje usled demineralizacije. Bele mrlje su znaci progresivnog gubitka minerala iz gledi zuba. Na demineralizovanim mestima gleđ je porozna, u nju se talože pigmentne materije (braon i crne boje) iz pljuvačke (hrane i bakterija). Ukoliko se u tom početnom stadijumu razvoja karijesa ne uklone uzročnici demineralizacije, dolazi do pucanja gleđi i pojave kaviteta (slika 1.) ${ }^{5}$.

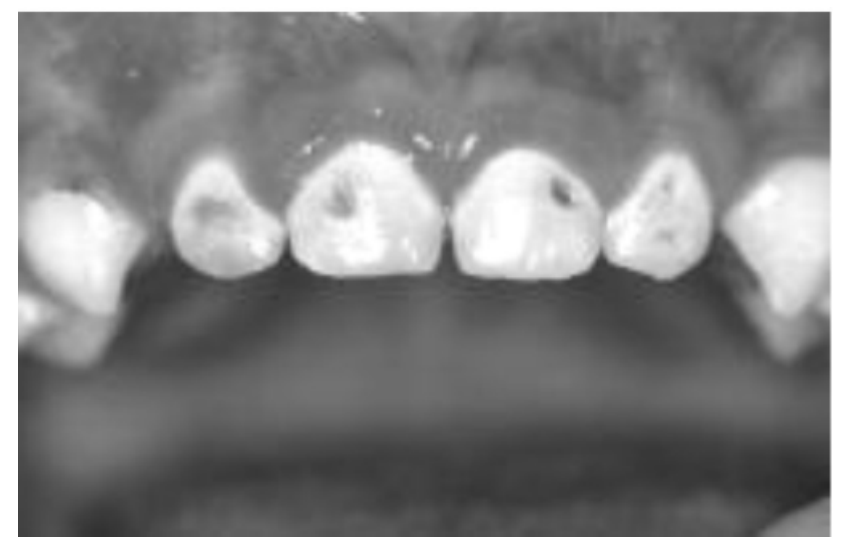

Karijes se brzo širi površinom gleđi, kružno zahvatajući celim obimom vratni deo krunice zuba, ubrzo zahvata i dentin, za veoma kratko vreme dolazi do destrukcije cele krunice, i ostaju samo korenovi ${ }^{5,16,19}$ (slika 2 i 3). Od 20 mlečnih zuba, prosečno je zahvaćeno karijesom 16 zuba ${ }^{5}$. Napredovanje karijesa može da bude izuzetno brzo i da za nekoliko nedelja od pojave belih mrlja, dođe do razaranja zuba ${ }^{16}$. To je i osnovna karakteristika ovog oboljenja po čemu se razlikuje od klasičnog karijesa mlečnih zuba koji uglavnom počinje u jamicama i fisurama griznih površina mlečnih molara ${ }^{14}$.

Lokalizacija karijesa ranog detinjstva u vratnoj trećini krunice zuba i kružno širenje se objašnjava lošijom mineralizacijom gleđi vratnog dela krunica svih mlečnih zuba koje se mineralizuju posle rođenja, u periodu kada se dete adaptira na spoljašnje uslove sredine (smatra se da karijes počinje na mestu gde je izražena neonatalna linija) ${ }^{4,16}$. Takođe je karakteristično da se subjektivne tegobe i bolovi javljaju kasno, tek po eksponiranju pulpe ili kada se javi infekcija, otok i
Enamel beneath and around the spots quickly develop white spots due to demineralization. White spots represent progressive loss of enamel minerals. Enamel is porous in demineralized surfaces and salivary pigments (brown and black) from food and bacteria penetrate it. Unless demineralizing factors are eliminated in this early stage, enamel fractures and cavity forms (figure 1). ${ }^{5}$

Slika 1. Karijes ranog detinjstva.

Demineralizacije gleđii kavitacije na gornjim mlečnim sekutićima Figure 1. Eearly childhood caries.

Demineralization of enamel and caries cavity on upper primary incisive.

Caries spreads quickly over enamel surface, circumferentially in the cervical region, soon spreads on dentine and in a very short time, there is a massive destruction of the entire tooth crown so that only roots remain (figures 2 and 3). 5, 16, 19 Out of 20 deciduous teeth, 16 teeth are carious on average. ${ }^{5}$ Caries spreading can be extremely fast so that only few weeks after the appearance of white spots teeth destruction occurs. ${ }^{16}$ This is the main characteristic that distinguishes this disease from classic form of deciduous teeth which starts in pits and fissures of the occlusal surfaces of deciduous molars. ${ }^{14}$

Early childhood caries localization in cervical third of tooth crown and circumferential spreading are explained with inferior mineralization of cervical enamel in all deciduous teeth since it occurs after birth, when the child adapts to external environment - it is believed that caries starts in the place of neonatal line). ${ }^{4,16}$ It is also characteristic that symptoms and pain occur late, after pulp is exposed or when infection, swelling and high temperature occur. 4 
temperatura ${ }^{4}$. Lečenje karijesa ranog detinjstva je težak i složen posao, a osnovni cilj terapije je da se uspori akutni tok obolenja, spreče komplikacije i ekstrakcija zuba ${ }^{20}$.

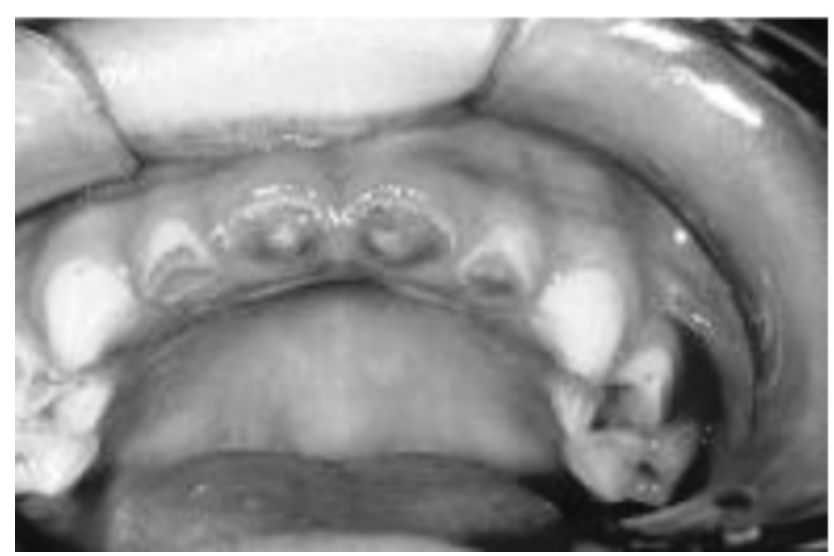

Slika 2. Karijes ranog detinjstva.

Razorene krunice gornjih mlečnih sekutića

Figure 2. Eearly childhood caries.

Destructed crowns of upper primary incisive.

\section{Etiologija}

Karijes zuba (caries dentis) je bakterijsko infektivno oboljenje modifikovano ugljenim hidratima iz ishrane ${ }^{21,22}$. Ishrana bogata ugljenim hidratima omogućava formiranje veće količine plaka na zubima i u uslovima loše oralne higijene uslovljava niži pH pljuvačke i češću pojavu karijesa $^{23,24}$. Karijes ranog detinjstva (KRD) predstavlja posebnu vrstu karijesa mlečnih zuba, u uzrastu odojčeta i malog $\operatorname{deteta}^{5}$. Za uzroke pojave karijesa ranog detinjstva postoje različite teorije. Neka opšta obolenja (tuberkuloza, rahitis, eksudativna dijateza i dr.) mogu biti uzrok predispozicije prema karijesu i olakšati delovanje drugih kariogenih faktora, ali sama ne mogu da prouzrokuju karijes ${ }^{5,17}$.

Etiologija obolenja je veoma složena i da bi došlo do njegove pojave moraju da budu ispunjeni određeni preduslovi među kojim se izdvajaju: mineralizacija mlečnih zuba, osobine pljuvačke, ishrana (prirodna- dojenje, veštačka -bočica sa cuclom, upotreba tečne i zaslađene hrane, česti neizbalansirani obroci, slatki međuobroci i sl.), zatim loše navike (umakanje cucle i varalice u med, uspavljivanje deteta sa cuclom u ustima i hranjenje deteta noću bočicom sa cuclom, noćni podoji), kao i ne održavanje oralne higijene deteta (rana kolonizacija usne šupljine acidogenim mikroorganizmima, prisustvo plaka ) ${ }^{5}$.

Karijes ranog detinjstva se najčešće smatra posledicom loših navika u ishrani odojčeta (upotreba ugljenih hidrata $\mathrm{u}$ ishrani, posebno saharoze, israna bočicom, korišćenje cucle i sl. $)^{4,16,17,25}$. Ranijih godina se velika pažnja davala nepravilnoj ishrani bočicom. Ishrana bočicom je smatrana glavnim i najčešćim uzrokom pojave ovog oblika karijesa međutim, on se nije javljao kod sve dece koja
Treatment of early childhood caries is difficult and complex job, with the main goal to slow down the acute course of the disease , prevent complications and tooth extraction. ${ }^{20}$

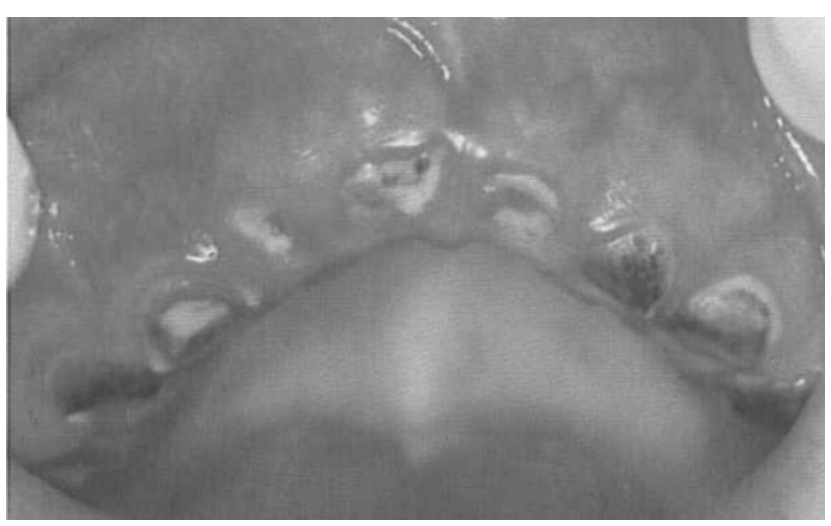

Slika 3. Karijes ranog detinjstva.

Razorene krunice gornjih mlečnih zuba

Figure 3. Eearly childhood caries.

Destructed crowns of upper primary teeth .

\section{Etiology}

Caries (caries dentis) is a bacterial infectious disease modified by food carbohydrates. ${ }^{21,22}$ Nutrition rich in carbohydrates enables large amounts of plaque to develop on teeth, lowers salivary $\mathrm{pH}$ and more frequent caries development in the bad oral hygiene. ${ }^{23,} 24$ Early childhood caries (ECC) is a special kind of caries in deciduous dentition in infants and toddlers. ${ }^{5}$ There are different theories concerning etiology of early childhood caries. Some systemic conditions can lead to caries predisposition and enable the effect of other factors, but cannot induce caries alone. ${ }^{5,17}$

Etiology of this disease is very complex and certain preconditions must be fulfilled among which are: mineralization of deciduous teeth, saliva properties, diet (natural - breast feeding, artificial - nursing bottles, sugarcontaining foods and drinks, frequent cariogenic snacks and drinks between meals etc.), bad habits and bad oral hygiene in early childhood (lead to early colonization of oral cavity with acidogenic microorganisms and dental plaque development). ${ }^{5}$

Early childhood caries is often considered a consequence of bad dietary habits in infants. 4, 16, 17, 25 Earlier, great attention was paid to inadequate bottle feeding. It was considered the most important and predominant cause for this disease but ECC did not occur in all children that used bottles and vice versa. This leads to the conclusion that nursing with sugar-containing food in infants and toddlers probably acts as an introduction into ECC develop- 
su je koristila ili se javljao i kod dece koja je nisu koristila. Sve to ukazuje da ishrana zaslađenom hranom pomoću bočice u doba dojenčeta i malog deteta verovatno predstavlja uvod u razvoj karijesa ranog detinjstva (KRD) ${ }^{5}$. Danas se sve više pažnje posvećuje ispitivanju uloge faktora sredine, čemu je doprinela široko prihvaćena multikauzalna etiologija karijesa ${ }^{5,21}$.

Karijes ranog detinjstva predstavlja ozbiljan zdravstveni problem naročito u siromašnim sredinama ${ }^{26}$. Da bi se sprečila pojava ovog obolenja mlečnih zuba potrebno je više pažnje posvetiti utvrđivaju tj.registrovanju visoko rizičnih grupa unutar rizične populacije i na taj način poboljšati kvalitet života ove dece. Prevalencija karijesa zuba u dece je značajno smanjena u proteklih 50 godina u razvijenim zemljama, ali se ipak smatra da je prevalencija karijesa ranog detinjstva u porastu ${ }^{27}$. Potvrdjeno je da se karijes ranog detinjstva javlja kod 3-45\% predškolske dece, a u nekim socio-ekonomskim subpopulacijama u SAD evidentiran je čak u 70-90\% odojčadi i dece predškolskog uzrasta ${ }^{15,28}$.

\section{Uloga Streptococcus mutans grupe i imunoglobulina pljuvačke}

Dete se rađa sa sterilnom usnom dupljom. Naseljavanje oralne sredine mikroorganizmima se ne sme, niti može sprečiti jer su oni normalni stanovnici usne duplje odgovrni za razvoj imunološkog sistema deteta ${ }^{2}$. Streptococcus mutans grupe je naseljavaju nicanjem prvih zuba, a najčešće se prenose direktno sa majke na dete (vertikalnom transmisijom $)^{5,6}$. Streptococcus mutans se, takodje, smatra najznačajnijim mikroorganizmom u pojavi karijesa ranog detinjstva ${ }^{5}$. Povećano prisustvo Streptococcus mutans grupa ne znači i da će se razviti karijes ranog detinjstva ali se povećava rizik u zavisnosti od prisustva drugih faktora.

Prisustvo fermentabilnih ugljenih hidrata $u$ ishrani deteta pomaže naseljavanje Streptococcus mutans grupa, čija kolonizacija omogućava rano formiranje dentalnog plaka na glatkim površinama zuba, da bi se u kasnijoj fazi javili drugi acidogeni mikroorganizmi (Lactobacilli, Actinomycete i dr) ${ }^{22,29,30}$. Važan epidemiološki dokaz veze Streptococcus mutans grupa sa pojavom karijesa su i brojna laboratorijska istraživanja koja su dokazala sposobnost ovih vrsta streptokoka da proizvode mlečnu kiselinu koja prouzrokuje demineralizaciju gleđi ${ }^{17,21,31}$. Primenom molekularne metode za identifikaciju bakteriskih vrsta povezanih sa karijesom ranog detinjstva $u$ dece sa karijesom i sa zdravin zubima utvrđene su značajne razlike u zastupljenosti oralnih mikroorganizama u njegovoj pojavi i razvoju: Streptococcus sanguis je bio povezan sa zdravim zubima i manjim brojem bakterija, dok su, Actinomyces gerencseriae, Bifidobacterium, Streptococcus mutans, Veillonella, Streptococcus salivarius, Streptococcus constellatus, Streptococcus parasanguinis i Lactobacillus fermentum bili u vezi sa karijesom. ment. ${ }^{5}$ Most recently, more attention is paid to environmental factors due to widely accepted multicausal etiology of caries. ${ }^{5,21}$

Early childhood caries is a serious health problem especially in poor communities. ${ }^{26}$ In order to prevent this disease, it is important to recognize high risk groups within population at risk and to improve the quality of life of such children. The prevalence of caries in children in vastly reduced in the last 50 years in developed countries. Still, it is believed that the prevalence of early childhood caries is rising. ${ }^{27}$ It is confirmed that early childhood caries occurs in 3-45\% of pre-school children while in some socioeconomic subpopulations in USA ECC was found in 70-90\% of infants and pre-school children. ${ }^{15,28}$

\section{The role of Streptococcus mutans group and salivary immunoglobulins}

A child is born with sterile oral cavity. Colonization of oral environment by microorganisms must not and cannot be stopped because microbes normal inhabitants of the oral cavity responsible for development of child's immune system. ${ }^{2}$ S. mutans groups inhabit the oral cavity after the eruption of very first teeth and are moste frequently transmitted directly from mother to child (vertical transmission). ${ }^{5,6} \mathrm{~S}$. mutans is also considered the most important microorganism in early childhood caries development. ${ }^{5}$ However, increased number of S. mutans groups does not necessarily mean that ECC will occur but increases the risk depending on other factors.

The presence of fermentable carbohydrates in child's diet helps colonization of S. mutans groups, which lead to early development of dental plaque on smooth tooth surfaces and other acidogenic microorganisms in the later stage. (Lactobacilli, Actinomyces spp. etc.). 22, 29, 30 Important epidemiological evidence of the relationship between $\mathrm{S}$. mutans and caries development are numerous laboratory studies on the ability of these Strptococci to produce acid products that induce enamel demineralization. $17,21,31$

Significant differences in predominance and the role of certain oral microorganisms were revealed using molecular identification method: Streptococcus sanguis was related to healthy teeth and small number of microbial species, while Actinomyces gerencseriae, Bifidobacterium, S. mutans, Veillonella, Streptococcus salivarius, S. constellatus, S. parasanguinis and Lactobacillus fermentum were associated with caries.

Several studies also conclude the primary role of Streptococcus mutans in caries etiology. ${ }^{21,32} \mathrm{~S}$. sobrinus was also associated with caries, but far less than S. mutans 
Ovim istraživanjem je još jednom potvrđena ${ }^{21}$ primarna uloga Streptococcus mutans-a u pojavi karijesa ${ }^{32}$. Streptococcus sobrinus je bio povezan sa karijesom, ali daleko manje i retko se nalazi bez prisustva Streptococcus mutansa. Lactobacillusi se navode kao sporedni uzročnici bolesti zuba zastupljeni u velikom broju kod prisustva otvorenih karijesnih lezija i velike učestalosti unošenja šećera. ${ }^{5,20,31,33}$.

Istraživanja Matee i sar. su pokazala da kod dece sa karijesom ranog detinjstva nema velike razlike u kolonizaciji Streptococcus mutans grupa iz plaka sa zdrave površine gleđi i kaviteta. Nivo Lactobacilla je bio 100 puta viši u plaku iz karijesne šupljine, dok su deca sa zdravim zubima imala značajno niže vrednosti kolonizacije Streptococcus mutans-a i Lactobacilla, što ukazuje na značaj rane infekcije Streptococcus mutans grupom u pojavi karijesa ranog detinjstva ${ }^{34}$. I drugi autori ističu značajan uticaj rane kolonizacije kariogenim bakterijama na povećanje karijes rizika u dece ${ }^{1,35,36}$. Istraživanja u ovoj oblasti uticala su da se veći broj autora bavio kliničkom oralnom mikrobiologijom. .,6,20,29.34,35,37 Tabela 2. prikazuje mikroorganizme povezane sa karijesnim procesom $5,38,39,40,41$. and seldom without the presence of S. mutans. Lactobacilli are said to be side factors in caries disease which predominate in open caries lesions and in cases of high frequency of sugar-containing meals. $5,20,31,33$

Matee et al. proved that in children with ECC there was no difference in S. mutans colonization from smooth surfaces plaque and from the cavity. Lacobacilli level wa 100 times higher in plaque from lesion cavity, while children with healthy teeth had significantly lower values of S. mutans and Lactobacilli colonization. This proves the importance of early infection with S. mutans group in early childhood caries development. ${ }^{34}$ Other authors, too, point out the importance of early colonization with cariogenic bacteria in increasing the risk of caries in children. ${ }^{1,35,36}$ Research in this field led to many more clinical microbiology studies. 2, 6, 20, 29, 34, 35, ${ }^{37}$ Table 2 shows microorganisms associated with caries process. ${ }^{5,38-41}$

Tabela 2.Oralne bakterije povezane sa karijesom zabeležene u literaturi Table 2.Oral bacterial associations with caries reported in the literature

\begin{tabular}{|c|c|c|c|}
\hline \multicolumn{4}{|c|}{ Bakterijske vrste Reference Tipične karakteristike Dodatne informacije } \\
\hline $\begin{array}{l}\text { Mutans streptococci } \\
\text { S. mutans } \\
\text { S. sobrinus }\end{array}$ & $\begin{array}{l}\text { Aluluusua et al., } 1996 \\
\text { Marchant et al., } 2001 \\
\text { Tanzer et al., } 2001\end{array}$ & \begin{tabular}{|l} 
- fermentacija prostih \\
ugljenih hidrata \\
- tolerancija na sredinu \\
sa niskom pH vrednošću
\end{tabular} & $\begin{array}{l}\text { - povezan sa frekvencijom karijesa } \\
\text { u male dece } \\
\text {-vertikalna transmisija } \\
\text {-naseljava oralnu šupljinu samo u } \\
\text { prisustvu tvrdog zubnog tkiva. } \\
\end{array}$ \\
\hline $\begin{array}{l}\text { Non-mutans streptococci } \\
\text { S. salivarius }\end{array}$ & Marchant et al., 2001 & & $\begin{array}{l}\text { - neodređena uloga u karijesnom procesu } \\
\text { - veoma obilan u oralnoj šupljini. }\end{array}$ \\
\hline $\begin{array}{l}\text { Lactobacilli } \\
\text { L. fermentum } \\
\text { L. casei }\end{array}$ & $\begin{array}{l}\text { Marsh and Martin, } 1999 \\
\text { Marchant et al., } 2001 \\
\text { Tanzer et al., } 2001\end{array}$ & $\begin{array}{l}\text { - broj u pljuvački reflektuje } \\
\text { konzumiranje prostih } \\
\text { ugljenih hidrataod strane } \\
\text { domaćina }\end{array}$ & $\begin{array}{l}\text { - sa dorsuma jezika } \\
\text { - uvek se razmnožava u karijesnom } \\
\text { dentinu } \\
\text { - čini ispod } 1 \% \text { od ukupno } \\
\text { obrađene mikroflore }\end{array}$ \\
\hline Enterococci & Tanzer et al., 2001 & $\begin{array}{l}\text {-nije često nađen u } \\
\text { oralnoj šupljini }\end{array}$ & $\begin{array}{l}\text { - imuno i medicinski komromitoovani } \\
\text { pacijenti bili su povezani sa njihovim } \\
\text { prisustvom u oralnoj šupljini }\end{array}$ \\
\hline $\begin{array}{l}\text { Actinomyces } \\
\text { A. naeslundii } \\
\text { A. odontolyticus } \\
\text { A. Israeli! }\end{array}$ & $\begin{array}{l}\text { Marchant et al., } 2001 \\
\text { Tanzer et al., } 2001\end{array}$ & $\begin{array}{l}\text { - korisnici ugljenih hidrata } \\
\text { - nisu povezani sa } \\
\text { inicijacijom KRD }\end{array}$ & $\begin{array}{l}\text { - izolovani iz karijesnih i sa zdravih } \\
\text { površina zuba } \\
\text { - više povezan sa zdravljem } \\
\text { - najzastupljenija vrsta Actinomyces-a } \\
\text { u dentalnom plaku dece sa } \\
\text { KRD je A Israeli }\end{array}$ \\
\hline Veilonella & $\begin{array}{l}\text { Bradshaw and Marsh, } 1998 \\
\text { Marchant et al., } 2001\end{array}$ & $\begin{array}{l}\text { - luče mlečne kiseline, obilni } \\
\text { u karijesnom dentinu }\end{array}$ & \\
\hline
\end{tabular}


Japanski autori su ustanovili da deca koja nemaju karijes, a kod koje je ustanovljen visok nivo Streptococcus mutans grupa, posle perioda od godinu dana imaju značajno veću incidencu karijesa od vršnjaka koji nisu imali ni karijes ni visok nivo Streptococcus mutans grupa u istom periodu života ${ }^{35}$. Kvantifikacija Streptococcus mutans grupa je korisna za ranu identifikaciju dece sa rizikom da razviju karijes ${ }^{39}$. Različiti rezultati koji se dobijaju pri ispitivanju uloge Streptococcus mutans grupa u pojavi karijesa verovatno nastaju kao posledica primene različitih mikrobioloških testova, razlika među decom koja se ispituju u ishrani, oralno higijenskim navikama, kao i nivou Streptococcus mutans grupa u usnoj šupljini majke ${ }^{21,38}$.

Ispitivanja Kohler i sar, su pokazala da $89 \%$ dece kod koje je došlo da rane kolonizacije Streptococcus mutans grupom u uzrastu od 2 godine ima dmft indeks 5 . Od dece koja nisu bila inficirana u 2 godini, samo $25 \%$ je imalo kip indeks 0,3 , u uzrastu od 4 godine ${ }^{35,42}$.

Obzirom da karijes zuba ima polietiološki karakter nije lako determinisati rizik za njegovu pojavu. Mehanizam nastanka i progresije ovog obolenja je složen process, koji se dešava u oralnoj sredini u kojoj pljuvačka neprekidno okružuje zube ${ }^{20}$. Pljuvačka ima poseban značaj u očuvanje zdravlja oralnih tkiva. Antimikrobiološku funkciju pljuvačke obavljaju proteini same pljuvačke: lizozim, laktoferin, laktoperoksidaza, histatidin, mucini, sekretorni $\operatorname{IgA}{ }^{7,20,43}$.

Tenovuo sa sar. je pronašao da neimunoglobulinski (lizozim, laktoferin, hipotiocianati) i imunološki antimikrobiološki salivarni faktori (ukupni IgA, anti-Streptococcus mutans IgA) koreliraju samo sa brojem novih inicijalnih karijesnih lezija zuba, što nije slučaj sa KIP, KPS i KS indeksima.Ovi autori daju značaj anti-Streptococcus mutans IgA i hipotiocijanatima u prevenciji ranih faza karijesa ${ }^{1}$. Dečja pljuvačka sadrži značajno niže koncentracije salivarnih imunoglobulina ${ }^{11,12}$. SIgA kombinovan sa $\operatorname{lgM}$ i IgG ukazuje na efikasnu zaštitu organizma.

Antitela na oralne bakterije kao i na Streptococcus mutans grupu, mogu se dokazati i u pljuvački, međutim njihova veza sa prirodnim imunitetom na karijes jos uvek nije potpuno jasna ${ }^{8,25,34}$. Neka istraživanja negiraju vezu između karijesa i imunoloških mehanizama u pljuvački ${ }^{23}$, dok druge studije imaju suprotne rezultate 9,45 .

Tokom brojnih istraživanja rasprostranjenosti karijesa i nivoa imunoglobulina ili specifičnih antitela, nije se moglo doći do određenih zaključaka, ali zato ispitivanjem salivarnih $\lg \mathrm{A}$ je utvrđeno da osobe sa zdravim zubima imaju niže ili više vrednosti u odnosu na osobe sa aktivnim karijesom ${ }^{46,47,48}$. Takođe i istraživanja pojave karijesa u osobe sa deficitom slgA pokazala su određenu povezanost između deficita u sekreciji slgA i rasprostranjenosti karijesa $^{8,45}$. Gregory i saradnici su našli da su nivoi IgA2 iz parotidne pljuvačke i serumskih IgG antitela na Streptococcus mutans antigene znaćajno veće $u$ osoba otpornih na pojavu karijesa, nego u karijes osetljivih osoba ${ }^{43}$. I kasnija istraživanja ovih autora otkrivaju da se imunogenost progutanih Streptococcus mutans-a menja zbog delovanja
Japanese authors revealed that children with no caries but with high level of S. mutans groups, had higher caries incidence after one year than children with no caries and low level of S. mutans. ${ }^{35}$ Quantification of S. mutans groups is useful for early identification of children at high risk for caries development. ${ }^{39}$ Different results in studies of S. mutans role in caries etiology probably occur due to application of different microbiology tests, differences in dietary or oral hygiene habits among children involved, but also the levels of S. mutans in mothers' mouths. ${ }^{21,38}$

Study of Kohler et al showed that $89 \%$ of children with early colonization of S. mutans had DMFT index 5 at the age of 2 . In children with no infection at the age of 2 , only $25 \%$ had 0.3 at the age of $4 .^{35,42}$

Since caries has multifactorial etiology, it is not easy to determine the risk for its development. The mechanism of initiation and progression of this disease is a complex process occurring in the oral environment in which saliva constantly flows over teeth. ${ }^{20}$ Saliva has a unique importance in maintaining oral tissues healthy. Antimicrobial function of saliva lies on salivary proteins: lysozyme, lactoperoxidase, histatidin, mucins, secretory IgA. ${ }^{7,20,43}$

Tenuvuo et al. found that non-immunoglobulin (lysozyme, lactoferrin, hypotiocyanats) and immune antimicrobial salivary factors correlated only with the number of new initial caries lesions, which was not the case with DMFT indices. These authors associate anti-S. mutans IgA and hypotiocyanats with caries prevention in early stages. ${ }^{1}$ Children's saliva contains significantly lower concentrations of salivary immunoglobulins. ${ }^{11,12}$ SIgA in combination with IgM and IgG is associated with efficient protection of host organism.

Antibodies for oral bacteria as well as S. mutans can be detected in saliva, but their relationship with natural immunity to caries is still unclear. ${ }^{8,25,34}$ Some studies deny this relationship ${ }^{23}$ while others have opposite results. ${ }^{6,45}$

In many studies, no indecisive conclusions could be made regarding the relationship between caries and the level of immunoglobulins or specific antibodies, but the study of salivary IgA revealed that individuals with healthy teeth had lower or higher levels compared to individuals with active caries. ${ }^{46-48}$ Other research showed certain relationship between the deficit in SIgA secretion and caries prevalence. ${ }^{8,45}$ Gregory et al. found that levels of $\operatorname{IgA}_{2}$ in parotid saliva and serum $\mathrm{IgG}$ antibodies for S. mutans were significantly higher in individuals at low than in those in high risk for caries. ${ }^{43}$ Later studies of the same authors revealed that immunogenicity of swallowed S. mutans changed due to saliva. These studies approve of the concept of immune regulation of caries by natural antibodies induced by salivary S. mutans antigens. ${ }^{49}$

The characteristic of caries as an infection is that, at the beginning of the disease, microorganisms do not 
pljuvačke. Ova istraživanja podržavaju koncept immune regulacije karijesa prisutnim (prirodnim) antitelima indukovanim pljuvačnim antigenima Streptococcus mutans- $\mathrm{a}^{49}$.

Specifičnost karijesa kao infekcije je što, mikroorganizmi na početku bolesti ne prodiru u gleđno tkivo, već se nalaze u velikim količinama (plakama) na površini gleđi i tu patogeno deluju. Zato je i reakcija imunološkog sistema organizma nešto drugačija nego kod infekcija ostalih tkiva. Plake u cervikalnom delu krunice su pod uticajem obe vrste imunoglobulina (serumskog i salivarnog) i u njima se može dokazati prisustvo sIgA, IgM i IgG, dok su plake na glatkim površinama krunice i u fisurama i jamicama samo pod uticajem imunoglobulina pljuvačke ${ }^{9,25}$. Smatra se da su salivarni IgA prva linija odbrane domaćina od patogenih mikroorganizama koji naseljavaju površine obložene spoljašnjim sekretima ${ }^{50}$.

Salivarni IgA se vezuje za strane materije, grupiše ih i inaktivira antigene toksine. Glavna funkcija sekretornih IgA antitela je da ograniči adherenciju mikroorganizama (njihovo vezivanje za površinu), isto kao i prodiranje stranih antigena u mukozu ${ }^{8,50}$. Uloga ovih antitela u kolonizaciji i regulisanju mikroorganizama je još uvek kontraverzna ${ }^{8}$.

Mikroorganizmi domaćina u oralnoj šupljini su obloženi sa sekretornim IgA ${ }^{47}$. Uprkos prisutnosti sIgA antitela mikroorganizmi koji su stanovnici oralne šupljine opstaju. Smatra se da mikroorganizmi domaćina mogu da opstanu u oralnoj sredini zato što su manje osetljivi ili mogu da izbegnu imune mehanizme ${ }^{8,19}$. Takođe je moguće da salivarni IgA ima uticaj na mikroorganizme domaćina, ali to je samo minimalni efekat među mnogim faktorima koji održavaju homeostazu od mikroorganizma domaćina ${ }^{2,19}$. Od kada je karijes povezan sa oralnim mikroorganizmima, uloga sekretornog IgA u kontroli oralnih mikroorganizama domaćina je preduslov za elaboraciju efektivne vakcine protiv ove bolesti ${ }^{8}$.

Do sada proučavanja moguće uloge imunoglobulina pljuvačke u mikrobiološkoj ekologiju usne šupljine su dala protivrečne rezultate (Tabela 3 ) 35,36,47,48,49,51. Kontrolni faktori koji utiču na oralni ekosistem mogu biti podeljeni u tri kategorije: one koji su povezani sa: a) domaćinom; b) mikroorganizmima; c) spoljašnjim faktorima ${ }^{6}$. Eksperimenti na životinjama su pokazali da sekretorni IgA koji su inkubirani protiv Streptococcus mutans-a dovode do redukcije kolonizacije ove bakterije i prevalencije karijesa ${ }^{8,50}$. Camling i saradnici su u istraživanjima pošli od činjenice da ako su antitela pljuvačke protiv Streptococcus mutans-a efikasna zaštita od karijesa, onda bi deca sa većim nivom ovih antitela trebala da imaju manji broj karijesnih zuba. Međutim nisu to potvrdili u svojim rezultatima ${ }^{51}$. Glukoziltransferaza je enzim suštinski važan za ćelijski zid i procese polimerizacije šećera Streptococcus mutans-a. Prisustvo antitela na ovaj antigen (protein) I/II, qlucosyltrans - ferase može u budućnosti biti od terapeutskog značaja ${ }^{7,8,19}$. Ispitivanje korelacije između salivarnih imunoglobulina i karijesa je veoma složen proces kod dece uzrasta od 1 do 3 godine, jer je imuni sistem još uvek nedovoljno razvijen ${ }^{12,36}$, a mikrobiološka flora u usnoj šupljini nestabilna tj. promenljiva ${ }^{8}$. penetrate enamel tissue, but remain on enamel surface in large quantities (dental plaque) where they act pathogenic. Therefore, the reaction of immune system is somewhat different than in infections of other tissues. Plaque in cervical region of the crown are influenced by both groups of immunoglobulins (serum and salivary) and the presence of $\operatorname{sg} \mathrm{A}, \operatorname{IgM}$ and $\operatorname{IgG}$ can be detected within them while plaque on smooth surfaces and in occlusal grooves are only affected by salivary immunoglobulins. ${ }^{9,23}$ It is believed that salivary IgA are the first line of host defense against pathogen microorganisms colonizing surfaces covered with excretes. ${ }^{50}$ Salivary IgA bonds alien structures, regroup them and inactivate toxic antigens. The main function of secretory IgA antibodies is to stop microbial adherence as well as penetration of alien antigens into mucosa. ${ }^{8,50}$ Microorganisms normally present in the mouth are covered with secretory IgA. ${ }^{47}$ In spite of the presence of $\operatorname{sIgA}$ antibodies microbial inhabitants of the oral cavity prevail. It is believed that host microorganisms can survive in the oral environment because they are less sensitive or can escape immune mechanisms. ${ }^{8,19}$ It is also possible that salivary IgA have an impact on host microorganisms, but it is only a minimal effect among numerous factors maintaining microbial homeostasis. ${ }^{2,} 19$ Ever since caries was associated with oral microorganisms, the role of secretory $\operatorname{IgA}$ in the control of oral host microorganisms is a precondition for developing effective vaccine against this disease. ${ }^{8}$

Research of the possible role of salivary immunoglobulins in microbial ecology of the oral cavity have had opposing results (table 3). ${ }^{35,36,47-79,51}$ Control factors that influence oral ecosystem can be divided into 3 categories: the ones associated with a) host; b) microorganisms; c) external factors. ${ }^{6}$ Animal experiments showed that secretory IgA incubated against S. mutans reduced colonization of this bacteria and caries prevalence. ${ }^{8,50}$ Camling et al. started their research from the hypothesis that if salivary antibodies for S. mutans were efficient in caries protection then children with higher level of these antibodies should have smaller number of carious teeth.But, they did not prove that in their research. ${ }^{51}$ Glucosyltransferase is an enzyme essentially important for cell wall and the process of polymerization of S. mutans sugars. The presence of antibodies for this antigen (protein) may in the future be of therapeutic importance. ${ }^{7,8,19}$ Studying correlation between salivary immunoglobulins and caries is a very complex process in children aged 1-3, because the immune system is still insufficiently developed. ${ }^{12,36}$ and microbial oral flora unstable. ${ }^{8}$ 
Tabela 3. Povezanost između pljuvačnih IgA antitela za Streptococcus mutans i prisustva karijesa

Table 3. Relationship between salivary IgA antibodies mutans streptococci and caries experience

\begin{tabular}{|c|c|c|c|c|}
\hline $\begin{array}{l}\text { UZRAST } \\
\text { (godine) }\end{array}$ & UZORAK & KORELACIJA & $\begin{array}{l}\text { ULOGA SIgA U } \\
\text { ZAŠTITI PROTIV } \\
\text { KARIJES }\end{array}$ & REFERENCE \\
\hline $2,5-5,5$ & $\begin{array}{l}\text { Ukupna } \\
\text { pljuvačka }\end{array}$ & $D A$ & $D A$ & $\begin{array}{l}\text { Everhart, D. L., K. Rothenberg, W. H. Carter, } \\
\text { Jr., and B. Klapper. 1978. The determination of } \\
\text { antibody to Streptococcus mutans serotypes in } \\
\text { saliva for children ages } 3 \text { to } 7 \text { years. J. Dent. Res. } \\
57: 631-635\end{array}$ \\
\hline $3-6$ & $\begin{array}{l}\text { Ukupna } \\
\text { pljuvačka }\end{array}$ & $D A$ & $D A$ & $\begin{array}{l}\text { Camling, E., and B. Köhler. 1987. Infection with } \\
\text { the bacterium Streptococcus mutans and salivary } \\
\text { IgA antibodies in mothers and their children. } \\
\text { Arch. Oral Biol. 32:817-823. }\end{array}$ \\
\hline $7-11$ & $\begin{array}{l}\text { Ukupna } \\
\text { pljuvačka }\end{array}$ & $D A$ & $D A$ & $\begin{array}{l}\text { Rose, P. T., R. L. Gregory, L. E. Gfell, and C. V. } \\
\text { Hughes. 1994. IgA antibodies to Streptococcus } \\
\text { mutans in caries-resistant and -susceptible } \\
\text { children. Pediatr. Dent. 16:272-275 }\end{array}$ \\
\hline $6-13$ & $\begin{array}{l}\text { Ukupna } \\
\text { pljuvačka }\end{array}$ & $N E$ & $N E$ & $\begin{array}{l}\text { Riviere, G. R., and L. Papagiannoulis. } 1987 . \\
\text { Antibodies to indigenous and laboratory strains } \\
\text { of Streptococcus mutans in saliva from children } \\
\text { with dental caries and from caries-free children. } \\
\text { Pediatr. Res. 9:216-220. }\end{array}$ \\
\hline $4-9$ & $\begin{array}{l}\text { Ukupna } \\
\text { pljuvačka }\end{array}$ & $N E$ & $N E$ & $\begin{array}{l}\text { Aaltonen, A. S., J. Tenovuo, O.-P. Lehtonen, } \\
\text { and R. Saksala. 1990. Maternal caries incidence } \\
\text { and salivary close-contacts with children affect } \\
\text { antibody levels to Streptococcus mutans in } \\
\text { children. Oral Microbiol. Immunol. 5:12-18 }\end{array}$ \\
\hline $3-14$ & $\begin{array}{l}\text { Ukupna } \\
\text { pljuvačka }\end{array}$ & $D A$ & $D A$ & $\begin{array}{l}\text { Bolton, R. W., and G. L. Hlava. 1982. Evaluation } \\
\text { of salivary IgA antibodies to cariogenic } \\
\text { microorganisms in children. Correlation with } \\
\text { dental caries activity. J. Dent. Res. } 61: 1225-1228\end{array}$ \\
\hline $1-4$ & $\begin{array}{l}\text { Ukupna } \\
\text { pljuvačka }\end{array}$ & $D A$ & $D A$ & $\begin{array}{l}\text { de Farias DG, Bezerra AC.: Salivary antibodies, } \\
\text { amylase and protein from children with early } \\
\text { childhood caries. Clin Oral Investig. } 2003 \\
\text { Sep;7(3):154-7. }\end{array}$ \\
\hline
\end{tabular}

\section{Zaključak}

Poznato je da pljuvačka ima specifičnu ulogu u održavanju oralnog zdravlja. Ona kontroliše metabolizam, atherenciju i rast patogenih mikroorganizama, poboljšava uklanjanje ugljenohidratnih ostataka hrane, omogućava remineralizaciju zuba i neutrališe organske kiseline proizvedene od strane acidogenih mikroorganizama koji dovode do demineralizacije zuba.

Etiologija KRD je slična ostalim tipovima dentalnog karijesa, ali njena biologija može da odstupa u nekim bitnim aspektima. Imajući u vidu da mikrobiološka oralna flora i odbrana domaćina nisu u potpunosti uspostavljene kod male dece kao i da su površine njihovih izniklih zuba još uvek nezrele, a tvrda zubna tkiva imunološki inaktivna, specifični pljuvačni odbrambeni mehanizmi protiv kolonizacije mokroorganizama i patogene aktivnosti kariogenih bakterija su veoma bitni. Ovi domaći odbrambeni mehanizmi uključuju specifične imune faktore pljuvačke ili seruma i gingivalne tečnosti i nespecifične antimikrobiološke sisteme.

\section{Conclusion}

It is well known that saliva has a specific role in maintaining oral health. It controls metabolism, adherence and growth of pathogenic microorganisms, enables removal of carbohydrate food remains, tooth remineralization and neutralizes organic acid products of acidogenic microorganisms that induce tooth demineralization.

Etiology of early childhood caries is similar to other types of dental caries, but its biology can differ in some important aspects. Having in mind that microbial oral flora and host defense are not fully developed in small children, that surfaces of their teeth are still immature and hard tissues immunologically inactive, specific salivary defense mechanisms against microbial colonization and pathogenic activity of cariogenic bacteria are very important. These host defense mechanisms involve specific immune factors of saliva or serum and gingival fluid as well as non-specific antimicrobial systems. 


\section{Literatura / References}

1. Grindefjord M, Dahllof G., Ekstrom G., Hojer B., Modeer T: Caries prevalence in 2- yer-old children.Caries Res, 1993, 27(6):505 - 503.

2. Marcotte, H, Rodrigue L, Coulombe C, Goyette N, Lavoie MC.: Colonization of the oral cavity by an unidentified streptococcus. Oral. Microbiol. Immunol, 1995, 10(3):168-174.

3. Tinanoff, N, O'Sullivan DM.: Early childhood caries: overview and recent findings. Pediatr. Dent, 1997, 19:12-16.

4. Vulović M.: Novine u stomatologiji, Savremena prevencija karijesa. Jugoslovenska pedijatriska škola, Igalo, 2001, 5(4): 165-170.

5. De Grauwe A, Aps JK, Martens LC.: Early Childhood Caries (ECC): what's in a name? Eur.J. Paediatr. Dent, 2004, 5(2): 62-70.

6. Marsh P, Martin M.: In Oral microbiology, 3rd ed. Ch,apman \& Hall, Ltd, London, United Kingdom,1992.

7. Gregory RL, Gfell LE, Malmstrom HS.: Differences in secretory $\operatorname{IgA}$ and serum antibodies to Streptococcus mutans isolated from caries-resistant and caries-susceptible subjects. Adv.Exp.Med.Biol, 1995, 37(1B): 1149-1152.

8. Marcotte H, Lavoie MC.: Oral Microbial Ecology and the Role of Salivary Immunoglobulin A. Microbiol. Mol. Biol. Rev, 1998, 62(1): 71-109.

9. Anđić J.: Osnovi oralne fiziologije, Naučna knjiga, Beograd, 1990.

10. Lee, SF.: Active release of bound antibody by Streptococcus mutans. Infect Immun, 1995, 63 : 1940- 1946.

11. Brandtzaeg P.: Synthesis and secretion of human salivary immunoglobulins. In: Garrett JR, Ekström J, Anderson LC, eds. Glandular mechanisms of salivary secretion. Frontiers of Oral Biology. Basel:Karger, 1998, 10:167-99.

12. Weemaes C, Klasen I, Goertz J, Beldhuis-Valkis M, Olafsson $\mathrm{O}$, Haraldsson A.: Development of immunoglobulin A in infancy and childhood. Scand. J. Immunol, 2003, 58(6) : 642-8.

13. Drury TF, Horowitz AM, Ismail Al, Maertens MP, Rozier RG, Selwitz RH.: Diagnosing and reporting Early Childhood Caries for research purposes. A report of a workshop sponsored by the National Institute of Dental and Craniofacial Research, the Health Resources and Services Administration and the Health Care Financing Administration. J Public Health Dent 1999, 59(3): 192-7.

14. Ismail AI, Sohn W.: A systematic review of clinical diagnostic criteria of early childhood Caries. J. Public Health Dent, 1999, 59(3):171-91.

15. Curzon ME, Preston AJ.: Risk groups: nursing bottle caries, caries in the elderly. Caries Res, 2004, 38(1):24-33.

16. Beloica D. i sar.: Dečja stomatologija, Naučna knjiga, Beograd, 2000.

17. Stošić P i sar.: Dečja i preventivna stomatologija, Naučna knjiga, Beograd, 1984.

18. Horowitz HZ.: Research issues in Early Childhood Caries. Community Dent. Oral.Epidemiol, 1998, 26(1): 67-81.

19. Cole MF.: Influence of secretory immunoglobulin A on ecology of oral bacteria, p. 131- 135. In.S.E. Mergenhagen, and B. Rosan (ed.), Molecular basis of oral microbial adhesion. American Society for Microbiology, Washington, D.C, 1985 .
20. Stanisavljević G.: Kvalitativna i kvantitativna analiza predstavnika grupe Streptococcus Mutans u etio- patogenezi karijesa. Doktorska disertacija, Niš, 1996.

21. Van Houte, J.: Role of micro-organisms in caries etiology. J.Dent. Res, 1994, 73 : 672- 681.

22. Vulović M, Carević M.: Infektivna priroda karijesa zuba. Zbornik referata i radova XII i XIII zdravstvenog vaspitanja u stomatologiji, Stom. Glas.S, 1998, 45(1): 5-9.

23. Cvetković A.: Uticaj faktora serine na prevalenciju karijesa u dece.Magistarski rad. Kruševac ,2001.

24. Vulović M, Cvetković A.: Influence of saliva as an environmental factor of caries occurrence.Book of Abstracts of the 7-th Congress of the Balcan Stomatological Society, Kusadasi, Turkey, Mrch 28-30, 2002.

25. Vulović M i sar.: Preventivna stomatologija, Naučna knjiga, Beograd, 2002.

26. Kaste LM, Selwitz RH, Oldakowski RJ, Brunelle JA, Winn DM, Brown LJ.: Coronal caries in the primary and permanent dentition of children and adolescents 1-17 years of age: United States, 1988-1991. J. Dent.Res, 1996, 75:531-40.

27. Marthaler TM:, O Mullane DM, Vrbic V.: The prevalence of dental caries in Europe 1990-1995. ORCA Saturday afternoom symposium 1995. Caries res 1996;30(4):237-55

28. Carević M.: Karijes ranog detinjstva. Zbornik rezimea; Naučni skup: Preventivna stomatologija,Beograd, 21 oktobar, 1999, 9-10.

29. Pearce C, Bowden GH, Evans M, Fitzsimmons SP, Johnson J, Sheridan MJ, Wientzen R, Cole MF.: Identification of pioneer viridans streptococci in the oral cavity of human neonates. J.Med. Microbiol. 1995.: 42:67-72.

30. Schupbach, P, Osterwalder V, Guggenheim B.: Human root caries: microbiota of a limited number of root caries lesions. Caries Res, 1996, 30(1):52-64.

31. Van Houte, J.: Bacterial specificity in the etiology of dental caries. Int. Dent. J, 1980, $30:$ 305-326.

32. Becker MR, Paster BJ, Leys EJ, Moeschberger ML, Kenyon SG, Galvin JL, Boches SK, Dewhirst FE, Griffen AL.: Molecular Analysis of Bacterial Species Associated with Childhood Caries. J. Clin. Microbiol, 2002 , 40(3):1001-9.

33. Smith, DJ, Taubman, MA.: Ontogeny of immunity to oral microbiota in humans. Crit. Rev. Oral Biol.Med, 1996, 3:109-133.

34. Matee MI, Mikx FH, Maselle SY, Van Palenstein Helderman WH.: Mutans streptococci and lactobacilli in breast - fed children with rampant caries. Caries Res.1992, 26(3) : 183-7.

35. Fujiwara T, Sasada E, Mima N, Ooshima T.: Caries prevalence and salivary mutans streptococci in 0-2-year-old children. Community Dent.Oral. Epidemiil, 1991, 19(3):151-4.

36. Cole MF, Bryan S, Evans MK, Pearce CL, Sheridan MJ, Sura PA, Wientzen RL, Bowden GH.: Humoral Immunity to Commensal Oral Bacteria in Human Infants: Salivary Secretory Immunoglobulin A Antibodies Reactive with S.mitis biovar 1, S.oralis, S.mutans, and Enterococcus faecalis during the First Two Years Life. Infect. Immun, 1999, 67(4):1878-86.

37. Radosavljević BJ: Izolovanje, biotipska diferencijacija i kariogeni potencijal Streptococcus mutans sojeva. Doktorska disertacija. Beograd, 1990. 
38. Alaluusua S, Matto J, Gronroos L, Innila S, Torkko H, Asikainen S, Jousimies-Somer H, Saarela M.: Oral colonization by more than one clonal type of mutans streptococcus in children with nursing- bottle dental caries. Arch. Oral.Biol, 1996, 41(2):167-73.

39. Buttner M: The salivary content of Streptococcus mutans in Basel children and adolescents (Der Mundflussigkeitsgehalt an Streptococcus mutans bei Easier Kinclern und Jugencllichen). Schweiz Monatsschr Zahnmed, 1993, 103(4): 409-12.

40. Tanzer JM, Livingston J, Thompson AM.: The microbiology of primary dental caries in humans. J. Dent. Educ, 2001, 65(10):1028-37.

41. Marsh P, Martin MV.: Dental Caries. In: Oral Microbiology (4th edition). Oxford: Wright; 1999, $6: 82-103$.

42. Kohler B, Andreen I, Jonsson B.: The earlier the colonization by mutans streptococci, the higher the caries prevalence at 4 years of age. Oral Microbiol. Immunol, 1988, 3:14-17.

43. Gregory RL, Kindle JC, Hobbs LC, Filler SJ, Malmstrom HS.: Function of anti-Streptococcus mutans antibodies:inhibition of virulence factors and enzyme neutralization. Oral. Microbiol. Immunol, 1990, 5:181-188.

44. Hocini H, Iscaki S, Bouvet JP, Pillot J.: Unexpectedly high levels of some presumably protective secretory immunoglobulin A antibodies to dental plaque bacteria in salivas of both caries-resistant and caries-susceptible subjects. Infect. Immun, 1993, 61:3597-3604.

\section{Autor odgovoran za korespondenciju}

Andrijana Cvetković,

Medicinski fakultet Univerziteta u Prištini,

Klinika za dečju i preventivnu stomatologiju,

Anri Dinana bb, Kosovska Mitrovica

Srbija

E-mail:anip@yubc.net
45. Rose PT, Gregory RL, Gfell LE, Hughes CV.: IgA antibodies to Streptococcus mutans in caries-resistant and -susceptible children. Pediatr. Dent, 1994, 16(4):272-275.

46. De Farias DG, Bezerra AC.: Salivary antibodies, amylase and protein from children with early childhood caries. Clin. Oral. Investig, 2003, 7(3):154-7.

47. Deslauriers N, Séguin J, Trudel L.: Differential recognition of oral indigenous bacteria by salivary immunoglobulin A and G. Microbiol. Immunol, 1987, 31:199-209.

48. Fernandes FRC, Nagao AT, Mayer MPA, Zelante F, Carneiro-Sampaio MMS.: Dental caries and salivary anti-Streptococcus mutans antibodies in IgA deficient children. Adv.Exp. Med.Biol, 1995, 37(1B):1145-8.

49. Gregory RL, Hobbs LC, Kindle JC, VanTo T, Malmstrom H.S.: Immunodominant antigens of Streptococcus mutans in dental caries- resistant subjects. Hum Antibodies Hybridomas, 1990, 1(3); 132-6.

50. Michalek, SM, Childers NK.: Development and outlook for a caries vaccinee. Crit. Rev. Oral Biol. Med, 1990, 1:37-54.

51. Camling E, Gahnberg L, Krasse B.: The relationship between IgA antibodes to Streptococcus mutans antigen in human saliva and breast milk and the numbers of indigenous oral S. mutans. Arch. Oral. Biol, 1987, 32:21-25.

\section{Address for correspondence}

Andrijana Cvetković,

Faculty of Medicine

Clinic of Pedodontic and Preventive Dentistry,

Anri Dinana bb, Kosovska Mitrovica

Serbia

E-mail: anip@yubc.net 